\title{
Expert System for Diagnosing Newborn Babies Disease Using the Sorgenfrei Similarity Method
}

\author{
AdriTriandhika Septyanto ${ }^{1 *}$, Imam Husni Al Amin ${ }^{2 *}$ \\ * TeknikInformatika, Universitas Stikubank Semarang \\ andikaadri@gmail.com.id ${ }^{1}$, imam@edu.unisbank.ac.id ${ }^{2}$
}

\begin{tabular}{l} 
Article Info \\
\hline Article history: \\
Received 2020-07-13 \\
Revised 2020-07-22 \\
Accepted 2020-08-2 \\
\hline
\end{tabular}

Keyword:

Expert System, Infant,

Neonates,

Sorgenfrei.

\begin{abstract}
Newborn neonates who are 0-28 days old. At that time the baby has a physical condition that is very weak and helpless to the surrounding environment. Newborns need special handling different from babies at the age of 1 month also above. Diagnosis also treatment is quickly required by the midwife in an emergency. Without there are still many midwives who have not been able to handle it properly, causing the baby's condition to become worse. To get fast and accurate handling information, we need a system in the form of an expert system. Expert systems can diagnose newborn diseases using the Sorgenfrei similarity algorithm. The system can display information about the type of disease, symptoms, solutions, and the percentage of similarity from the results of consulting the symptoms input. The results of testing the system with the consultation of the symptoms included got the highest percentage of similarity results $53.33 \%$. The percentage of similarity results below $20 \%$ will be entered into the revised table which will later be corrected by experts. This expert system is built based on a website that can be accessed by all midwives who need handling information
\end{abstract}

\section{INTRODUCTION}

Neonatal is defined as a clinical syndrome in aninfant 28 days of life or younger[1].Newborn children screening is a must for examining every newborn for persuaded dangerous or potentially deadly disorders that aren't otherwise obvious at birth[2]. Weightless or below average becomes a problem that often occurs in newborns. In an emergency, diagnosis and help are needed quickly. Delay in providing help can result in death to the baby. In 2012 the number of neonatal infant deaths was 19 deaths per 1000 live births. In 2017 there were 15 deaths per 1000 live births [3]. In 5 years there was only a significant decrease in mortality.

Lack of adequate health facilities, inadequate diagnosis, and still minimal human resources in the field of health, causes a high rate of newborn mortality. These events, more frequently caused by improper intrauterine transfer of maternal blood oxygen to the fetus resulting in an acute inadequate supply of oxygen to the fetal organs and tissues[4]. Data collection starting from handling pregnancy, managing data of health workers, managing information on pregnancy problems by the community, delivery by medical personnel and neonatal visits need to be managed properly to produce information about good handling so that neonatal recovery can be adjusted by taking action - appropriate measures for neonatal issuance based on information data that has been generated with these problems, the authors want to create an expert system that is useful for diagnosing newborn diseases.

In the case of report submission, there is a problem caused by the delay in submission of the report which causes the data obtained is not up to date, so the decision making based on the data becomes inaccurate.To provide information about the disease accurately and precisely needed a system that can do this simultaneously. The most appropriate system used for this problem is the expert system.

Expert systems are computer programs that are derived from a branch of computer science research called Artificial Intelligence (AI)[5]. Expert systems are used to solve a large number of problems such as decision-making[6]. Computer-based systems using 
knowledge, facts and reasoning techniques for an expert to solve problems. The inference engine applies the rules to known facts to deduce new facts [7].From the problem the current proposed expert system is specialized in the diagnosis ofdisease in newborns [8].

\section{RESEARCH METHODS}

\section{A. Similarity Algorithm}

A similarity algorithm is a way to calculate the similarity of two objects by comparing the similarity based on syntax or semantic values. The coefficient is adopted to display the quantity of similarity. Algorithms for solving many pattern recognition problems such as classification, clustering, and data retrieval problems for more details can be seen in Table1.

TABEL I

SIMILARITY FORMULA

\begin{tabular}{|c|c|c|}
\hline & $\mathbf{1}$ (presence) & $\mathbf{0}($ Absence) \\
\hline 1 (presence) & $\mathrm{a}=\mathrm{i} \cdot \mathrm{j}$ & $\mathrm{b}=\overline{\mathrm{i}} \cdot \mathrm{j}$ \\
\hline $0($ Absence $)$ & $\mathrm{c}=\mathrm{i} \cdot \overline{\mathrm{j}}$ & $\mathrm{d}=\overline{\mathrm{i}} \cdot \overline{\mathrm{j}}$ \\
\hline
\end{tabular}

Information:

$a=$ number of attributes where the values of $i$ and $j$ are equal to 1 (presence), which means positive matches

$b=$ number of attributes where the values of $i$ and $j$ are

$(0,1)$, which means i absence mismatches

$\mathrm{c}=$ number of attributes where the values of $\mathrm{i}$ and $\mathrm{j}$ are $(1,0)$, which means $\mathrm{j}$ absence mismatches

Similarities usually fall in the range of 0 to 1 , where 0 there are absolutely no matching or similar cases, and a value of 1 means that it has a $100 \%$ match.

\section{B. Similaritas Sorgenfrei}

The similarity is a measure of the closeness of an object with other objects. Then what is meant by Sorgenfrei similarity is the method used to calculate the similarity between the distance of two probability distributions with the formula referred to in equation (1).

$$
S=\frac{a^{2}}{(a+b) x(a+c)}
$$

Information:

$\mathrm{S}=$ Value Similarity

$\mathrm{a}=$ The same number of attributes between consultation and data stored in the database.

$\mathrm{b}=$ The amount of data stored in the database, which is not in the consultation.

$\mathrm{c}=$ Number of consulting data attributes, which are not stored in the database.

\section{System Description}

Website-based expert system for newborns using the Sorgenfrei method. This application allows users to view newborn disease information. To start the application process, it is divided into two access rights, namely user and admin. The user can consult with the selected symptoms experienced by the baby. While the admin can make a consultation like a user plus the admin can input information, symptoms, and diseases.

In implementing this child expert system, it takes 4 stages of the process, namely retrieve, reuse, revise, and retain. The retive process is the process of finding data in a database with method sorgrenfrei. Then the reus system process that provides the results of the calculation of the greatest similarity value will be used as a solution to the disease. Furthermore, in the process of revisingprocess of revising the values that come out of the proposed solutionreus process that still does not meet the requirements will be accompanied in a special table, for later repaired experts to find the right solution [9]. After the revision process is finished and the most appropriate solution is found, the expert will add the relation to the relation table which can later be used for solving similar cases in the future [10].

Admin's work process begins with logging in to the login page, then the admin will be directed to a display that has a choice of menus, illnesses, symptoms, solutions, and relationships to maintain data and information. For more clearly how the system works User work system architecture can be seen in Picture 1, while the admin work systemarchitecture can be seen in Figure 2

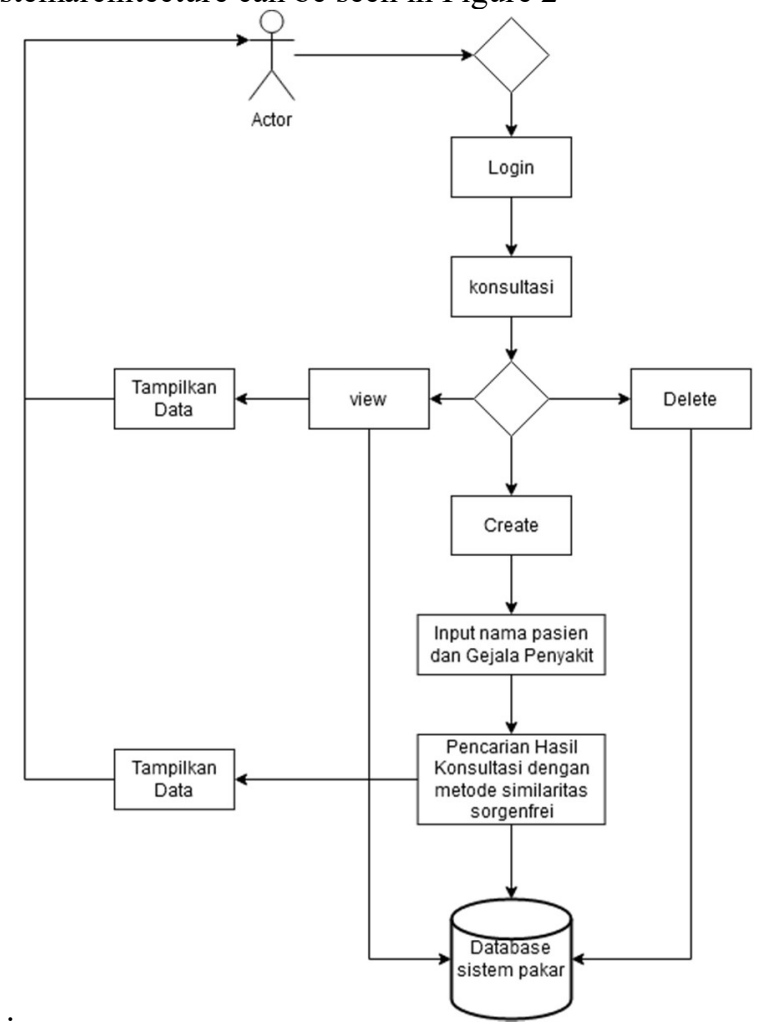

Fig.1 User system architecture. 
The picture above explains the flow of the user's role in using the system to consult newborn diseases

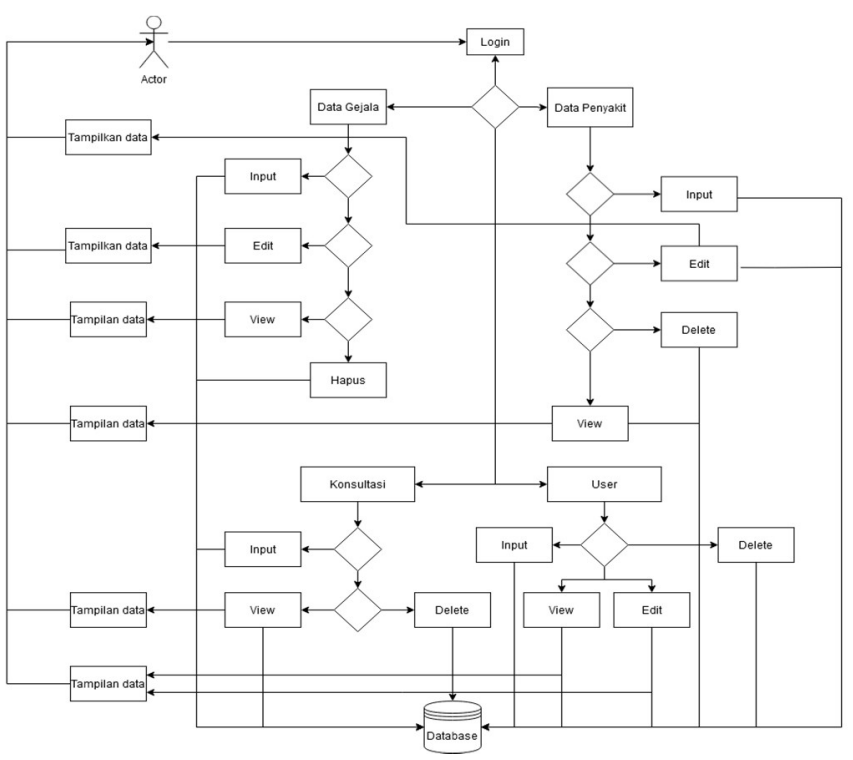

Figure 2.Admin system architecture

In the figure 2 above is an admin role that can access all the menus or features that are in the system created.

\section{Knowledge Representation}

The symptoms table is used as a knowledge base that will be compared with many symptoms, both those that have been recorded and those that have never been recorded. This database is used as a basis for comparing a user's consultation with a pre-existing knowledge base. In the symptom table, there is a symptom code that shows the sequential number of symptoms and the name of the disease symptoms that exist in newborns. For more details, can be seen in Table 2.

TABLE II

NAME OF SYMPTOMS

\begin{tabular}{|c|l|}
\hline $\begin{array}{c}\text { Symptom } \\
\text { Code }\end{array}$ & \multicolumn{1}{|c|}{ Name Symptoms } \\
\hline G01 & Jaundice occurs on days 2 and 3 \\
\hline G02 & Extreme movements are not active \\
\hline G03 & yellow eye sclera \\
\hline G04 & the baby won't suckle \\
\hline G05 & yellow baby jaundice 24 hours after birth \\
\hline G06 & stay for 7-14 days \\
\hline G07 & $\begin{array}{l}\text { jaundice of yellow baby accompanied by } \\
\text { LBW (BW }<2500 \text { gram), infection }\end{array}$ \\
\hline G08 & Difficulty defecating \\
\hline G10 & Hard stool \\
\hline G11 & $\begin{array}{l}\text { Stomach hard or palpable stool mass on } \\
\text { the abdominal wall }\end{array}$ \\
\hline G12 & Pain in the anal area \\
\hline G13 & Fresh blood comes out due to anal injury. \\
\hline G14 & BAB $>$ 4x / day \\
\hline G15 & Unconscious \\
\hline
\end{tabular}

\begin{tabular}{|c|c|}
\hline G16 & Sunken eyes \\
\hline G17 & Restless / fussy \\
\hline G18 & $\begin{array}{l}\text { Non-elastic skin (pinch the skin of the } \\
\text { stomach's slow return) }\end{array}$ \\
\hline G20 & Diarrhea persists for 2 weeks \\
\hline G21 & $\begin{array}{l}\text { Acute gastroenteritis in infants aged }>3 \\
\text { months }\end{array}$ \\
\hline G22 & Clinical syndromes \\
\hline G23 & Active movement (looking healthy) \\
\hline G24 & Self limited disease \\
\hline G25 & $\begin{array}{l}\text { Responsifterhadapterapisuportif yang } \\
\text { diberikan (kesadaranbaik) }\end{array}$ \\
\hline G26 & Cough \\
\hline G27 & Sometimes sneezing \\
\hline G28 & Secretions from the nose (runny nose) \\
\hline G30 & $\begin{array}{l}\text { Body weight at birth LBW = } 1500-2499 \\
\text { grams }\end{array}$ \\
\hline G31 & $\begin{array}{l}\text { Body weight at birth BBLSR }=1000- \\
1499 \text { grams }\end{array}$ \\
\hline G32 & Weight at birth BBLER $=<1000$ grams \\
\hline G33 & Body length $<45 \mathrm{~cm}$ \\
\hline G34 & Head circumference $<32 \mathrm{~cm}$ \\
\hline G35 & Chest circumference $<30 \mathrm{~cm}$ \\
\hline G36 & Inactive movements (hypotonic muscles) \\
\hline G37 & Head bigger than body, thin and fine hair \\
\hline G38 & Soft skull bones \\
\hline G39 & Simple-shaped ears and little cartilage \\
\hline G40 & small / not formed nipples \\
\hline G41 & breathing $<20 \mathrm{x} /$ minute \\
\hline G42 & $\begin{array}{l}\text { Thin, transparent skin, lanugo (fine hair), } \\
\text { especially on the forehead, forehead } \\
\text { temples and arms, visible blood vessels }\end{array}$ \\
\hline G43 & $\begin{array}{l}\text { Genetalia is not perfect, in women the } \\
\text { labia minor has not been covered by labia } \\
\text { majora, the clitoris protrudes. In small } \\
\text { scrotal LK men, the testes are not palpable }\end{array}$ \\
\hline G44 & Reflexes suck, swallow and cough weak \\
\hline G45 & Edema Extremities (swelling) \\
\hline G46 & Convulsions \\
\hline G47 & Fever (temperature $\left.>37.5^{\circ} \mathrm{C}\right)$ \\
\hline G48 & Irregular eye movements \\
\hline G49 & Throw up \\
\hline G50 & $\begin{array}{l}\text { The movements of the hands and feet } \\
\text { (extremities) are not active }\end{array}$ \\
\hline G51 & Pain in the head and back \\
\hline G52 & Baby reflex is absent \\
\hline G53 & Cry loud and high pitch \\
\hline G54 & Decreased appetite \\
\hline G55 & Occurs 6-72 hours after birth \\
\hline G56 & Respiratory disorders \\
\hline G57 & Pale / blue baby \\
\hline G58 & Jaundice / jaundice \\
\hline G59 & Diarrhea \\
\hline G60 & Bloated \\
\hline G61 & No response \\
\hline G62 & $\begin{array}{l}\text { Release the ties or clamps of the cord that } \\
\text { is still attached }\end{array}$ \\
\hline G63 & Redness on the umbilical cord \\
\hline G64 & There is a secret on the umbilical cord \\
\hline
\end{tabular}




\begin{tabular}{|l|l|}
\hline G65 & Slimy cough \\
\hline G67 & $\begin{array}{l}\text { Rapid baby breathing }>60 x / \text { minute } \\
\text { (tachypnea) }\end{array}$ \\
\hline G68 & Hypertherm (temperature $>37.5^{\circ}$ C) \\
\hline G69 & Nausea \\
\hline G70 & Urinating is not as usual \\
\hline G71 & $\begin{array}{l}\text { Trismus (difficulty opening the mouth) is } \\
\text { mild }\end{array}$ \\
\hline G72 & Stiff / inelastic skin \\
\hline G73 & Perutpapan / keras \\
\hline G74 & Stomach board / hard \\
\hline G75 & No seizures \\
\hline G76 & There is no respiration disorder \\
\hline G77 & $\begin{array}{l}\text { Trismus (difficulty opening mouth) } \\
\text { moderate }\end{array}$ \\
\hline G78 & $\begin{array}{l}\text { The presence of excitatory seizures, no } \\
\text { spontaneous seizures }\end{array}$ \\
\hline G79 & Mild dysphagia \\
\hline G80 & $\begin{array}{l}\text { Trismus (difficulty opening the mouth) is } \\
\text { severe }\end{array}$ \\
\hline G81 & Spastic muscles \\
\hline G82 & spontaneous seizures \\
\hline G83 & Tachycardia (DJB $>160 x /$ minute) \\
\hline G84 & Apneu attack \\
\hline G85 & Severe dysphagia \\
\hline G86 & Autonomous system activity increases \\
\hline G87 & Gong face \\
\hline G88 & Tilted eyes \\
\hline G89 & Labiokizis \\
\hline G90 & Palatoskizis \\
\hline G91 & Labiopalatoskizis \\
\hline G92 & Gnatoskizis \\
\hline G93 & There is no anal canal (atresia ani) \\
\hline G94 & Polydactyl \\
\hline G95 & Sindaktili \\
\hline G96 & Polysindactyl \\
\hline G97 & Yellow skin \\
\hline H99 & Takiph-pitched tears \\
\hline & \\
\hline & \\
\hline & \\
\hline
\end{tabular}

Disease tables are used to determine diseases suffered by newborns. Disease determination is based on symptom data in new cases that are matched with symptom data in old cases that show the highest similarity. Disease data displayed in the consultation are data of disease that has the highest similarity value., calculated based on the Sorgenfrei algorithm. In the disease table, there is code data that shows the sequence of disease codes, and newborn disease names can be seen in Table 3 .

TABLE III

DISEASE NAME

\begin{tabular}{|l|l|}
\hline $\begin{array}{l}\text { Disease } \\
\text { Code }\end{array}$ & \multicolumn{1}{c|}{ Disease Name } \\
\hline P01 & $\begin{array}{l}\text { Troubled Newborns / with } \\
\text { Complications }\end{array}$ \\
\hline P02 & Physiological jaundice \\
\hline P03 & Pathological jaundice \\
\hline
\end{tabular}

\begin{tabular}{|l|l|}
\hline P04 & Kern Ikterus \\
\hline P05 & Constipation \\
\hline P06 & Acute diarrhea \\
\hline P07 & Chronic diarrhea \\
\hline P08 & Cough and cold \\
\hline P09 & Sepsis Neonatorum \\
\hline P10 & Umbilical Cord Bleeding \\
\hline P11 & Pneumonia \\
\hline P12 & Mild Tetanus \\
\hline P13 & Medium Tetanus \\
\hline P14 & Heavy Tetanus \\
\hline P15 & Congenital Abnormalities \\
\hline
\end{tabular}

\section{RESULT AND DISCUSSION}

\section{A. Results}

The results of the research from the expert system with the Sorgenfrei method for diagnosing of newborn diseases can be seen in Table 4

TABLE IV

TEST RESUlT

\begin{tabular}{|c|c|c|}
\hline Selected Symptoms & $\begin{array}{c}\text { Emerging } \\
\text { diseases }\end{array}$ & $\begin{array}{c}\text { Similarity } \\
\text { Percentage }\end{array}$ \\
\hline $\begin{array}{l}\text { 1. Defecate more } \\
\text { than } 4 \text { times per }\end{array}$ & Acute diarrhea & $\begin{array}{l}\text { similaritas } 0,5333 \\
\text { or } 53,33 \%\end{array}$ \\
\hline $\begin{array}{l}\text { day. } \\
\text { 2. Unconscious. } \\
\text { 3. Concave Eyes }\end{array}$ & $\begin{array}{l}\text { Newborns have } \\
\text { problems or } \\
\text { complications }\end{array}$ & $\begin{array}{l}\text { similaritas } 0,0476 \\
\text { or } 4,76 \%\end{array}$ \\
\hline $\begin{array}{ll}\text { 4. } & \text { Restless or } \\
\text { Fussy } \\
\text { 5. } \\
\text { Movement is } \\
\text { less active } \\
\text { (Hypotonic } \\
\text { Muscle). } \\
\text { 6. Edema } \\
\text { Extremities } \\
\text { (Swelling). }\end{array}$ & Cough and cold & $\begin{array}{l}\text { similaritas } 0,0417 \\
\text { or } 4,17 \%\end{array}$ \\
\hline
\end{tabular}

\section{B. Discussion}

The expert system uses the sorgenfrei method to diagnose newborns calculated by sorgenfrei, referred to in equation (2).

$$
S=\frac{a^{2}}{(a+b)(a+c)}
$$

$\mathrm{S}=$ Value Similarity

$\mathrm{a}=$ The same number of attributes between consultation and data stored in the database.

$\mathrm{b}=$ The amount of data stored in the database, which is not in the consultation.

$\mathrm{c}=$ Number of consulting data attributes, which are not stored in the database.

Then the consultation is carried out by selecting the symptoms of newborn diseases, namely:

1. Chapter more than 4 times per day.

2. Unconscious.

3. Concave Eyes

4. Restless or Fussy 
5. Movement is less active (Hypotonic Muscle)

6. Edema Extremities (Swelling).

The results of the expert system consultation with Sorgenfrein's similarity to diagnose newborn diseases are:

1. Calculation of acute diarrheal disease

\begin{tabular}{|c|c|}
\hline New case & Acute diarrhea \\
\hline $\begin{array}{l}\text { The symptoms: } \\
\text { 1. defecate more than } 4 \\
\text { times per day. } \\
\text { 2. Unconscious. } \\
\text { 3. Concave eyes. } \\
\text { 4. Restless or fussy. } \\
\text { 5. Movement is less } \\
\text { active (Hypotonic } \\
\text { Muscle). } \\
\text { 6. Edema Extremities } \\
\text { (swelling) }\end{array}$ & $\begin{array}{l}\text { The symptoms: } \\
\text { 1. Defecate more than } 4 \\
\text { times per day.. } \\
\text { 2. Unconscious. } \\
\text { 3. Concave eyes } \\
\text { 4. Restless or fussy. } \\
\text { 5. Skin Not elastic. }\end{array}$ \\
\hline
\end{tabular}

Based on calculations with Sorgenfrein's similarity, acute diarrhea has a value indicated in equation (3).

$$
S=\frac{a^{2}}{(a+b)(a+c)}
$$

$\mathrm{a}=4, \mathrm{~b}=2, \mathrm{c}=1$

so the similarity value $\mathrm{S}=0.5333 \times 100 \%=53.33 \%$.

2. Calculation of newborn problems with problems or complications

\begin{tabular}{|c|c|}
\hline New case & $\begin{array}{l}\text { Newborns have problems } \\
\text { or complications }\end{array}$ \\
\hline \begin{tabular}{ll}
\multicolumn{2}{l}{ Symptoms: } \\
1. Defecate more than 4 \\
times per day. \\
2. Unconscious. \\
3. Sunken eyes. \\
4. Restless or fussy. \\
5. Inactivity (Hypotonic \\
Muscle). \\
6. Edema \\
Extremities(swelling)
\end{tabular} & \begin{tabular}{|l} 
Symptoms: \\
1. \\
Body weight at birth \\
lbw $=1500-2499$ \\
grams
\end{tabular} \\
\hline
\end{tabular}

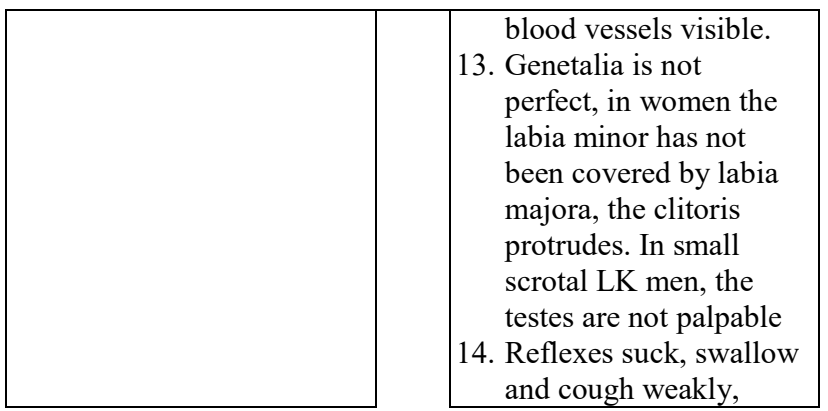

Based on calculations with Sorgenfrein's similarity, newborns with problems or complications have a value indicated in equation (4):

$$
S=\frac{a^{2}}{(a+b)(a+c)}
$$

$\mathrm{a}=2, \mathrm{~b}=4, \mathrm{c}=12$

so the similarity value $S=0,0476 \times 100 \%=4,76 \%$

\begin{tabular}{|c|c|}
\hline Kasusbaru & DiareAkut \\
\hline $\begin{array}{ll}\text { Symptoms: } \\
\text { 1. } & \text { Chapter more than } \\
& 4 \text { times per day. } \\
\text { 2. } & \text { Unconscious. } \\
\text { 3. } & \text { Sunken eyes. } \\
\text { 4. } & \text { Restless or fussy. } \\
\text { 5. Inactivity } \\
\text { (Hypotonic } \\
\text { Muscle). } \\
\text { 6. Edema } \\
\text { Extremities } \\
\text { (swelling) }\end{array}$ & $\begin{array}{l}\text { Symptoms: } \\
\text { 1. Restless or fussy } \\
\text { 2. Cough } \\
\text { 3. } \\
\begin{array}{l}\text { Cometimes it } \\
\text { contains } \\
\text { 4. }\end{array} \\
\begin{array}{l}\text { Secret out of the } \\
\text { nose (runny nose) }\end{array}\end{array}$ \\
\hline
\end{tabular}

7. Calculation of cold cough disease

Based on calculations with Sorgenfrein's similarity, cold cough has a value indicated in equation (5).

$\mathrm{a}=1, \mathrm{~b}=5, \mathrm{c}=3$

$$
S=\frac{a^{2}}{(a+b)(a+c)}
$$

so the similarity value $S=0,0417 \times 100 \%=4,17 \%$

\section{IV.CONCLUSION}

The results of the research that the researchers have described in the previous chapters, the Sorgenfrei similarity method for diagnosing newborn diseases can be summarized as follows:

1. The Sorgenfrei similarity method can be used to find diagnoses of newborn diseases to users.

2. Sorgenfrei similarity produces a final value of similarity between 0 zero and 1 one.

3. Consultation results that show a percentage below $20 \%$ will be accommodated in the revised table to find the most appropriate solution. 
4. The highest value of the research trial from the random selection of symptoms gets a percentage of $53.33 \%$.

\section{REFERENCES}

[1] E. M. R. Shehab El-Din, M. M. A. El-Sokkary, M. R. Bassiouny, and R. Hassan, "Epidemiology of neonatal sepsis and implicated pathogens: A Study from Egypt," Biomed Res. Int., vol. 2015, 2015, doi: 10.1155/2015/509484.

[2] S. S. A. Naser and I. A. El Haddad, "An Expert System for Genital Problems in Infants," vol. 2, no. May, pp. 83-86, 2016.

[3] Ministry of Health, "Indonesia Health Profile 2014," Kementeri. Kesehat. Republik Indones., vol. 51, no. 6, p. 40, 2015, doi: 10.1037/0022-3514.51.6.1173.

[4] M. A. M. Reis, N. R. S. Ortega, and P. S. P. Silveira, "Fuzzy expert system in the prediction of neonatal resuscitation," Brazilian J. Med. Biol. Res., vol. 37, no. 5, pp. 755-764, 2004, doi: 10.1590/S0100-879X2004000500018.

[5] Bassem S. Abu-Nasser, "Medical Expert Systems Survey," Med. Arh., vol. 49, no. 3-4, pp. 107-112, 2017.

[6] Alaa N. Akkila and Samy S. Abu Naser, "Proposed expert system for calculating inheritance in Islam," World Wide J. Multidiscip. Res. Dev., vol. 2, no. 9, pp. 38-48, 2015.

[7] Amin, I. H. A, \& Suhartono, S. (2012) Expert Systems Detecting Hair Damage Using Rule Base Reasoning with the Forward Chaining Method. JSINBIS (Journal of Business Information Systems), 2 (3), 134-138

[8] A. Z. A. O. Samy S. Abu Naser, "an Expert System for Diagnosing Eye Diseases Using Clips," Theor. Appl. Inf. Technol., vol. 3, no. December, pp. 923-930, 2008.

[8] S. S. A. Naser and I. A. El Haddad, "An Expert System for Genital Problems in Infants," Int. J. Med. Res., vol. 1, no. May, pp. 83-86, 2016, [Online]. Available: http://ssrn.com/abstract=2814417.

[9] A. Rahman, C. Slamet, W. Darmalaksana, Y. A. Gerhana, and M. A. Ramdhani, "Expert System for Deciding a Solution of Mechanical Failure in a Car using Case-based Reasoning," IOP Conf. Ser. Mater. Sci. Eng., vol. 288, no. 1, 2018, doi: 10.1088/1757-899X/288/1/012011.

[10] H. Y. A. Abutair and A. Belghith, "Using Case-Based Reasoning for Phishing Detection," Procedia Comput. Sci., vol. 109, pp. 281-288, 2017, doi: 10.1016/j.procs.2017.05.352. 